\title{
CHARACTERIZATION AND USE OF SUBSTRATES COMPOSED OF ORGANIC WASTE IN THE PRODUCTION OF Colubrina glandulosa PERKINS SEEDLINGS
}

\author{
Victória Maria Monteiro Mendonça ${ }^{1 *}$, Vitória Duarte S. Silva², Tiago Paula da Silva ${ }^{3}$. Ariovaldo Machado F. \\ Júnior $^{4}$, Sidinei Júlio Beutler ${ }^{5} \&$ Marcos Gervasio Pereira ${ }^{6}$ \\ 1*Programa de Pós-Graduação em Ciências Ambientais e Florestais, Universidade Federal Rural do Rio de Janeiro, Seropédica, RJ, Brasil - \\ e-mail: viic_monteiro@hotmail.com \\ ${ }^{2}$ Universidade Federal Rural do Rio de Janeiro, Curso de Engenharia Florestal, Seropédica, RJ, Brasil - e-mail: viccduartes@ gmail.com \\ ${ }^{3}$ Universidade Federal Rural do Rio de Janeiro, Curso de Agronomia, Seropédica, RJ, Brasil - e-mail: tiago8paula6@hotmail.com \\ ${ }^{4}$ Programa de Pós-Graduação em Ciências Ambientais e Florestais, Universidade Federal Rural do Rio de Janeiro, Seropédica, RJ, Brasil - e - \\ mail: arijunior01@ hotmail.com \\ ${ }^{5}$ Programa de Pós-Graduação em Ciência do Solo, Universidade Federal Rural do Rio de Janeiro, Seropédica, RJ, Brasil - e-mail: \\ s.parana@yahoo.com.br \\ ${ }^{6}$ Departamento de Solos, Instituto de Agronomia, Universidade Federal Rural do Rio de Janeiro, Seropédica, RJ, Brasil - e -mail: \\ mgervasiopereira01@gmail.com
}

Received for publication: 11/09/2019 - Accepted for publication: 13/03/2020

\begin{abstract}
Resumo
Caracterização e utilização de substratos constituídos de resíduos orgânicos na produção de mudas de Colubrina glandulosa Perkins. Os resíduos orgânicos urbanos vêm ganhando destaque na composição de substratos, pois são fontes de nutrientes naturais e uma alternativa sustentável para mitigação dos impactos ambientais causados pelo descarte indevido de resíduos. Objetivou-se caracterizar química e fisicamente os substratos a base de resíduos orgânicos e avaliar o desenvolvimento de mudas da espécie Colubrina glandulosa utilizando resíduo da poda arbórea urbana compostado. Para tal, foram utilizadas diferentes proporções de composto orgânico (CP), terra de horizonte A (SAH), esterco bovino curtido (BM) e vermiculita, acondicionados em tubetes citropote com volume de 1,7 L. Determinou-se a relação $\mathrm{C} / \mathrm{N}$, capacidade de retenção de água $(10 \mathrm{hPa})$, condutividade elétrica, macro e microporosidade e porosidade total dos substratos antes de sua utilização. As análises de fertilidade dos substratos foram realizadas antes e após a produção das mudas. Ao decorrer do desenvolvimento das mudas foram mensuradas as variáveis altura $(\mathrm{H})$ e diâmetro de coleto (SD) aos 60, 90 e 120 dias. Aos 90 e 120 dias, as mudas foram segmentadas em parte aérea e raiz para determinação da massa seca de cada compartimento, índice de qualidade de Dickson (DQI) e teores de nutrientes (N, P, K, Ca e Mg). Pode-se observar nos tratamentos com altas proporções de CP boas características físicas, em contrapartida apresentaram grande limitação química no desenvolvimento das mudas. Já os tratamentos à base de $\mathrm{BM}, \mathrm{SAH}$ e menor proporção de $\mathrm{CP}$, apresentaram as maiores médias para $\mathrm{H}$, SD, relação H/SD e DQI.

Palavras-chave: Composto orgânico; espécie arbórea nativa; poda arbórea urbana.
\end{abstract}

\begin{abstract}
Urban organic waste has been gaining prominence in the composition of substrates, as it is a source of natural nutrients and a sustainable alternative to mitigate environmental impacts caused by improper waste disposal. The aim of this study was to characterize chemically and physically substrates based on organic waste and to evaluate the development of Colubrina glandulosa seedlings using composted urban tree pruning waste. Treatments consisted of different proportions of organic compost (CP), soil from the A horizon (SAH), aged manure $(\mathrm{BM})$ and vermiculite, kept in tubes $\left(\right.$ Citropote ${ }^{\circledR}$ ) with volume of $1.7 \mathrm{~L}$. C/N ratio, water holding capacity $(10 \mathrm{hPa})$, electrical conductivity, macroporosity, microporosity and total porosity of substrates before their use were determined. Substrate fertility analyses were carried out before and after seedling production. During the development of the seedlings, height $(\mathrm{H})$ and stem diameter (SD) were measured at 60,90 and 120 days. At 90 and 120 days, the seedlings were divided into shoots and roots to determine the dry mass of each compartment, Dickson quality index (DQI) and contents of nutrients (N, P, K, Ca and Mg). After the analysis of the results, it can be observed that the treatments with high proportions of CP had better physical characteristics, but also showed chemical limitation in the development of the seedlings. Treatments based on $\mathrm{BM}, \mathrm{SAH}$ and lower proportion of $\mathrm{CP}$ had the highest average results for $\mathrm{H}, \mathrm{SD}, \mathrm{H} / \mathrm{SD}$ ratio and DQI.

Keywords: organic compost; seedling production; native tree species; urban tree pruning.
\end{abstract}

\section{INTRODUCTION}

In the search for sustainable alternatives and mitigation of environmental impacts, the use of urban organic waste in the composition of fertilizers and substrates becomes a viable alternative in the production of seedlings, aiming at the reuse of nutrients contained in these materials and the reduction of production costs

FLORESTA, Curitiba, PR, v. 51, n. 2, p. 381-390, abril/jun 2021.

Mendonça, V. M. M. et.al.

ISSN eletrônico 1982-4688

DOI: $10.5380 /$ rf.v51 i2. 69177 
(ARAÚJO et al., 2017; FARIA et al., 2014). Among the existing waste, biomass from urban tree pruning can constitute a relevant part of all waste generated in a city.

The Brazilian Association of Technical Standards (ABNT, 2004), by the NBR-10.004 standard (linked to NBR-10.007, which regulates waste sampling), classifies solid waste into Class I: hazardous; Class II: non-inert, and Class III: inert. Tree pruning waste is in Class II, along with cardboard and paper, and may have the properties of combustibility, biodegradability and solubility in water. Due to these characteristics, green waste becomes potential environmental polluters, so their stabilization and correct disposal are essential.

The production of high-quality seedlings can be affected by several factors, especially the substrates used and the proportions of their respective components, which must have favorable physical, chemical and biological characteristics (CALDEIRA et al., 2013), due to their wide use in production. The quality of seedlings has an influence on their establishment and growth after planting in the field, making the stage of production in nurseries of extreme importance.

A substrate as understood as all solid material, natural or synthetic, residual, mineral or organic that is distinct from the soil, placed in a container in its pure form or in mixture, allowing the development of the root system, playing a supporting role for the plant (GAZOLA et al., 2015). The proportion of components that constitute a certain substrate, in low or high amounts, may improve or compromise germination, as well as causing malformation of plants and symptoms of deficiency or excess of some nutrient (MESQUITA et al., 2012).

The demand for seedlings of native forest species has gained prominence in recent decades, due to the need to comply with protective measures, implement programs of recovery of degraded areas by planting native tree seedlings, and intensify urban afforestation projects (SILVA et al., 2017).

Among the native forest species, Colubrina glandulosa Perkins, popularly known in Portuguese as 'sobrasil', 'saguaraji', among others, belonging to the Rhamnaceae family, stands out. This species is part of the group of early secondary ones, occurring in the Amazon (Firm-Ground Forest, Ombrophilous Forest), Cerrado (Cerrado), and Atlantic Forest (Semideciduous Seasonal Forest, Ombrophilous Forest) biomes. It is a mediumsized tree, with a height between 5 and $20 \mathrm{~m}$, with rapid to moderate monopodial growth, reaching volumetric production of up to $12.90 \mathrm{~m}^{3} \mathrm{ha}^{-1}$ year-1 , at seven years of age (LORENZI, 2002). It has favorable characteristics for use in reforestation (CAMARA et al., 2017), forest restorations, enrichment of secondary vegetation in permanent preservation areas (LORENZI, 2002), as well as for agroforestry systems and urban afforestation.

Considering the need for knowledge about the effect of different combinations of substrates, obtained from organic waste, that allow the production of forest seedlings in quantity and quality, this study aimed to chemically and physically characterize the substrates based on organic waste and evaluate the development of Colubrina glandulosa Perkins seedlings using composted urban pruning waste, from the city of Rio de Janeiro.

\section{MATERIAL AND METHODS}

The experiment was conducted in a non-climate controlled greenhouse in the Department of Soils of the Institute of Agronomy of the Federal Rural University of Rio de Janeiro (UFRRJ), located in the municipality of Seropédica - RJ, Brazil, at $22^{\circ} 44^{\prime}$ and $43^{\circ} 42^{\prime}$ and 26 meters of altitude. According to Köppen's classification, the climate is Aw, tropical with rainy summer and dry winter.

C. glandulosa seeds were subjected to the dormancy breaking process, through chemical scarification, and immersed in a volume of concentrate (95-98\% A.R.) sulfuric acid $\left(\mathrm{H}_{2} \mathrm{SO}_{4}\right)$ corresponding to twice their volume, in glass beaker (BRANCALION et al., 2011). After 15 minutes, the contents of the beaker were homogenized with a glass rod. After more 30 minutes, in a total of 45 , the seeds were removed and washed in running water for 10 minutes. Then, they were dried at room temperature on a benchtop (CAMARA et al., 2017) at the Laboratory of Soil Genesis and Classification (LGCS) of UFRRJ.

After overcoming dormancy, the seeds were sown in trays filled with washed sand, irrigated twice a day, where they remained until the transplanting stage $( \pm 30$ days) in the Luiz Fernando Oliveira Capellão Forest Nursery of the Forestry Department of the Forest Institute of UFRRJ.

The experiment was conducted from November 2018 to February 2019, totaling 120 days. Figure 1 shows the values of air temperature and relative humidity referring to the experimental period. The data were obtained through an automatic datalogger (HOBO - U12-012 model). 


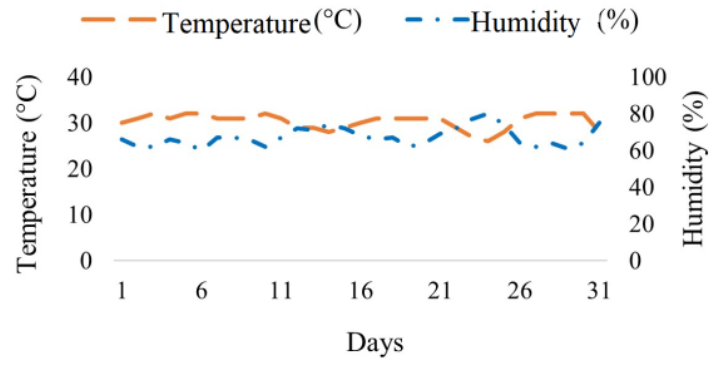

Figura 1: Temperatura e umidade média ocorridas na casa de vegetação durante a produção das mudas de $C$. glandulosa. Período: Novembro de 2018 a Janeiro de 2019.

Figure 1: Average temperature and humidity during the production of $C$. glandulosa seedlings. Period: November 2018 through January 2019.

A completely randomized design (CRD) was adopted, with five treatments, 20 replicates, with each seedling being one replicate, totaling 100 seedlings.

For the formulation of treatments (substrates), four components were used in different proportions: soil from A horizon (SAH) of an Argissolo Vermelho-Amarelo (Ultisol); organic compost produced by aerobic composting of the urban tree pruning waste $(\mathrm{CP})$ of the city of Rio de Janeiro-RJ (waste provided by the Municipal Urban Cleaning Company - COMLURB; composting carried out in the Department of Soils-UFRRJ); aged bovine manure (BM) from the milk cattle sector of UFRRJ; and vermiculite (Table 1).

Tabela 1: Componentes e proporções dos substratos utilizados (\%) na formulação dos tratamentos. Table 1: Substrate components and proportions used $(\%)$ in the formulation of treatments.

\begin{tabular}{ccccc}
\hline Treatment & BM & SAH & CP & Vermiculite \\
\hline T1 & & & $\mathbf{( \% )}$ & - \\
T2 & 20 & 80 & 20 & - \\
T3 & - & 80 & - & 20 \\
T4 & 20 & 60 & 20 & 20 \\
T5 & - & 60 & 10 & 10 \\
\hline
\end{tabular}

Legend: BM: bovine manure; SAH: soil from A horizon; CP: compost of urban pruning waste.

For preparation and mixing of the components, the CP, SAH and BM were sieved through 8-mm mesh, mixed manually, until reaching good homogenization. The mixtures were prepared on the basis of volume. Chemical analyses of the substrates were performed before and after seedling production (0 and 120 days) according to the methodology described by Normative Instruction $\mathrm{N}^{\circ} 17$ of May 21, 2007 (BRASIL, 2007) and Teixeira et al. (2017).

$\mathrm{C}$ and $\mathrm{N}$ as well as $\mathrm{C} / \mathrm{N}$ ratio were determined by the dry method, from $250 \mathrm{mg}$ of sample, previously macerated in porcelain mortar and processed in a 100-mesh sieve, by oxidation at $900{ }^{\circ} \mathrm{C}$, to obtain $\mathrm{C}$ and $\mathrm{N}$ at $900{ }^{\circ} \mathrm{C}$ (CHN-600 Carlo Erba EA-1110, Italy).

The physical characterization was performed using three samples of each substrate, based on the variables macroporosity (MacroP), microporosity (MicroP), total porosity (TP) and water holding capacity at $10 \mathrm{hPa}$ ( $\left.\mathrm{WHC}_{10}\right)$, according to the method of De Boodt and Verdonck (1972).

Seedlings were produced in recycled and returnable plastic containers (Citropote ${ }^{\circledR}$ ), with height of $20 \mathrm{~cm}$ and diameter of $12 \mathrm{~cm}$, holding a volume of $1.7 \mathrm{~L}$. Later, the containers were filled manually with the different substrate formulations. No other nutrient source was added.

The containers were allocated in suspended beds inside the greenhouse. C. glandulosa seedlings were transplanted to the containers early in the morning, one seedling per container with heights ranging between 5 and $7 \mathrm{~cm}$. The seedlings were irrigated manually, with a 200-mL graduated cup, twice a day, in the early morning and late afternoon.

Evaluations of quality of the seedlings and the effects of the treatments on their development were performed by measuring height $(\mathrm{H})$, with a millimeter ruler $(\mathrm{cm})$, and stem diameter $(\mathrm{SD})$ using a digital caliper with resolution of $0.01 \mathrm{~mm} / 0.0005$ " and accuracy of $\pm 0.03 \mathrm{~mm}$, every 30 days until the end of the experience, being at 60,90 and 120 days. 
Destructive analyses were performed in ten seedlings per treatment at 90 days and ten seedlings per treatment at 120 days, determining the following parameters: shoot dry mass (SDM) and root dry mass (RDM). For this, the shoot (SH) and root (R) compartments were dried in a forced air circulation oven at $65^{\circ} \mathrm{C}$ for 72 hours (reaching constant weight). Then, the material was weighed on analytical balance with precision of four decimal places.

The ratio between shoot height and stem diameter (H/SD), the ratio between shoot dry mass and root dry mass (SDM/RDM), as well as Dickson quality index (DICKSON et al., 1960), were calculated by the following mathematical expression:

$$
D Q I=\frac{T D M}{\left(\frac{H}{C D}\right)+\left(\frac{S D M}{R D M}\right)}
$$

Where: DQI: Dickson quality index; TDM: total dry mass (g); H: seedling height (cm); CD: stem diameter (mm); SDM: shoot dry mass (g); RDM: root dry mass (g).

Dry samples of shoots and roots were ground in a IKA A11 basic analytical mill, 0.2-g samples were weighed and then subjected to sulfuric digestion, for subsequent quantification of total nitrogen (N), phosphorus $(\mathrm{P})$, potassium $\left(\mathrm{K}^{+}\right)$, calcium $\left(\mathrm{Ca}^{+2}\right)$ and magnesium $\left(\mathrm{Mg}^{+2}\right)$. $\mathrm{N}$ contents were obtained by wet oxidation in steam drag distillation; P contents by spectrophotometry; and $\mathrm{K}^{+}$contents by flame photometry (TEDESCO et al., 1995). $\mathrm{Ca}^{+2}$ and $\mathrm{Mg}^{+2}$ contents were obtained by atomic absorption spectrometry (TEDESCO et al., 1995).

The data were subjected to normality analysis (Shapiro-Wilk test, 5\%) and homogeneity of the error variance (Levene test, 5\%). Data that met the statistical assumptions were subjected to a parametric statistical analysis (Tukey test, 5\%). Data that did not meet the statistical assumptions were subjected to the nonparametric statistical analysis (Kruskal-Wallis test, 5\%).

\section{RESULTS}

All substrate compositions showed adequate values of MacroP (or aeration space), but all also had low values of MicroP, according to the classification of Gonçalves et al. (2000); Gonçalves and Poggiani (1996) (Table 2). The substrates T3 and T4 showed the best physical properties, with MacroP, TP and $\mathrm{WHC}_{10}$ classified as adequate (GONÇALVES; POGGIANI, 1996).

Tabela 2: Características físicas das diferentes formulações de substratos utilizados na produção de C. glandulosa. Table 2: Physical characteristics of the different substrate formulations used in the production of C. glandulosa.

\begin{tabular}{cccccc}
\hline Treat. & $\begin{array}{c}\text { Composition }(\boldsymbol{\%}) \\
\text { BM:SAH:CP:V }\end{array}$ & MacroP (AS) & MicroP & TP & $\begin{array}{c}\text { WHC10 } \\
\left(\mathbf{m}^{-3} \mathbf{m}^{-\mathbf{3}}\right)\end{array}$ \\
\hline T1 & $20: 80: 0: 0$ & 37 & 20 & 57 & 0.18 \\
T2 & $0: 80: 20: 0$ & 33 & 20 & 53 & 0.18 \\
T3 & $20: 60: 0: 20$ & 45 & 32 & 77 & 0.30 \\
T4 & $0: 60: 20: 20$ & 45 & 35 & 80 & 0.32 \\
T5 & $10: 70: 10: 10$ & 34 & 24 & 58 & 0.21 \\
\hline
\end{tabular}

Legend: MacroP (AS): macroporosity (aeration space); MicroP: microporosity; TP: total porosity; WHC 10 : water holding capacity at 10 hPa tension.

In general, all treatments had low values for the chemical characteristics analyzed of the substrates (before) (Table 3), except for $\mathrm{pH}$ and $\mathrm{Mg}^{+2}$ for all treatments and $\mathrm{Ca}^{+2}$ for $\mathrm{T} 2$, according to the classification of Gonçalves and Poggiani (1996).

The chemical characterization of the treatments, before and after the production of the seedlings, highlights the low contents of macronutrients available for the seedlings. The increase in the contents of $\mathrm{Ca}^{+2}$ ( $\mathrm{T} 2$ and T4), $\mathrm{Mg}^{+2}$ (T5) and P (T1, T2, T3 and T4) after seedling production (Table 3) may be an indication that the composting process, to which the urban tree pruning was subjected, did not occur completely, resulting in an nonstabilized compost. 
Tabela 3: Análise química dos substratos antes e após a produção de mudas de C. glandulosa (0 e 120 dias). Table 3: Chemical analysis of substrates before and after production of C. glandulosa seedlings (0 and 120 days).

\begin{tabular}{|c|c|c|c|c|c|c|c|c|c|}
\hline \multirow{2}{*}{\multicolumn{2}{|c|}{ Treatments }} & pH & EC & $\mathbf{N a}^{+}$ & $\mathbf{K}^{+}$ & $\mathrm{Ca}^{+2}$ & $\mathbf{M g}^{+2}$ & Al & $\mathbf{P}$ \\
\hline & & $\left(\mathbf{H}_{2} \mathbf{O}\right)$ & $\mathrm{mS} \mathrm{m}^{-1}$ & \multicolumn{5}{|c|}{$\mathrm{cmol}_{\mathrm{c}} \mathrm{dm}^{-3}$} & $\mathrm{mg} \mathrm{dm}^{-3}$ \\
\hline $\mathrm{T} 1$ & \multirow{5}{*}{ 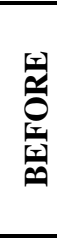 } & 7.69 & 1.68 & 0.030 & 0.008 & 8.20 & 11.5 & 0.0 & 59.88 \\
\hline $\mathrm{T} 2$ & & 6.54 & 0.24 & 0.029 & 0.007 & 14.03 & 7.57 & 0.2 & 19.83 \\
\hline $\mathrm{T} 3$ & & 7.28 & 0.86 & 0.028 & 0.007 & 5.53 & 9.13 & 0.0 & 59.78 \\
\hline $\mathrm{T} 4$ & & 6.48 & 0.23 & 0.031 & 0.007 & 7.23 & 8.43 & 0.0 & 23.79 \\
\hline $\mathrm{T} 5$ & & 6.78 & 0.64 & 0.029 & 0.007 & 7.10 & 7.6 & 0.0 & 38.13 \\
\hline $\mathrm{T} 1$ & \multirow{5}{*}{ 委 } & 7.4 & 0.88 & 0.024 & 0.006 & 6.43 & 7.65 & 0.0 & 72.63 \\
\hline $\mathrm{T} 2$ & & 7.28 & 0.24 & 0.025 & 0.007 & 8.95 & 5.55 & 0.0 & 40.54 \\
\hline $\mathrm{T} 3$ & & 7.29 & 0.81 & 0.030 & 0.007 & 6.53 & 9.08 & 0.0 & 62.22 \\
\hline $\mathrm{T} 4$ & & 7.33 & 0.17 & 0.030 & 0.007 & 7.38 & 7.08 & 0.0 & 47.99 \\
\hline $\mathrm{T} 5$ & & 7.25 & 0.46 & 0.029 & 0.007 & 6.70 & 9.23 & 0.0 & 36.14 \\
\hline
\end{tabular}

Legend: $\mathrm{pH}$ - hydrogen potential; $\mathrm{EC}$ - electrical conductivity; $\mathrm{Na}$ - sodium; $\mathrm{K}$ - potassium; Ca - calcium; $\mathrm{Mg}$ - magnesium; $\mathrm{Al}$ - aluminum; P - phosphorus; T1 (20:80:0:0); T2 (0:80:20:0); T3 (20:60:0:20); T4 (0:60:20:20); T5 (10:70:10:10).

The $\mathrm{C} / \mathrm{N}$ ratios of all treatments are outside the appropriate range (8 to $12 / 1$ ), according to the classification of Gonçalves and Poggiani (1996) (Table 4). However, for T1 and T3, the values were very close to the ideal, being considered acceptable. The highest $\mathrm{C} / \mathrm{N}$ ratio was found in $\mathrm{T} 4$, which contains $\mathrm{CP}$ and does not contain $\mathrm{BM}$ in its formulation.

Tabela 4: Teores totais de carbono $(\mathrm{C})$, nitrogênio $(\mathrm{N})$ e relação carbono/nitrogênio $(\mathrm{C} / \mathrm{N})$ das diferentes formulações de substratos (tratamentos).

Table 4: Total contents of carbon $(\mathrm{C})$, nitrogen $(\mathrm{N})$ and carbon / nitrogen $(\mathrm{C} / \mathrm{N})$ ratios of the different substrate formulations (treatments).

\begin{tabular}{|c|c|c|c|c|}
\hline \multirow{2}{*}{ Treat. } & \multirow{2}{*}{$\begin{array}{l}\text { Composition (\%) } \\
\text { BM:SAH:CP:V }\end{array}$} & $\mathbf{C}$ & $\mathbf{N}$ & \multirow{2}{*}{$\mathbf{C} / \mathbf{N}$} \\
\hline & & \multicolumn{2}{|c|}{$(\%)$} & \\
\hline $\mathrm{T} 1$ & $20: 80: 0: 0$ & 8 & 0.6 & 14 \\
\hline $\mathrm{T} 2$ & 0:80:20:0 & 9 & 0.6 & 16 \\
\hline $\mathrm{T} 3$ & 20:60:0:20 & 8 & 0.6 & 13 \\
\hline $\mathrm{T} 4$ & $0: 60: 20: 20$ & 10 & 0.6 & 18 \\
\hline T5 & 10:70:10:10 & 8 & 0.5 & 16 \\
\hline
\end{tabular}

Legend: Treat.: treatment; BM: bovine manure; SAH: soil from A horizon; CP: compost of urban pruning waste; V: vermiculite.

For the variables $\mathrm{H}, \mathrm{SD}$ and $\mathrm{H} / \mathrm{SD}$ ratio, there was statistical difference for all measurement dates (Table 5). T3 showed significantly higher values of $\mathrm{H}$ and $\mathrm{SD}$ at 90 and 120 days, followed by T1 and T5. For H/SD ratio, the T5 treatment, with the lowest mean, was the most balanced in relation to the proportion of shoot size to root size. Treatments T2 and T4, which had the highest percentage of CP, were statistically inferior for all variables, with very similar mean values.

Tabela 5: Valores médios de altura (H) da parte aérea e diâmetro de coleto (SD) das mudas de C. glandulosa aos 60, 90 e 120 dias e relação altura/diâmetro de coleto (H/SD) aos 120 dias.

Table 5: Average values of shoot height (H) and stem diameter (SD) of C. glandulosa seedlings at 60, 90 and 120 days and height/diameter ratio (H/SD) at 120 days.

\begin{tabular}{|c|c|c|c|c|c|c|c|c|}
\hline \multirow{3}{*}{ Treat. } & \multirow{3}{*}{$\begin{array}{l}\text { Composition (\%) } \\
\text { BM:SAH:CP:V }\end{array}$} & \multicolumn{3}{|c|}{$\mathrm{H}(\mathrm{cm})$} & \multicolumn{3}{|c|}{ SD (mm) } & \multirow{3}{*}{ H/SD } \\
\hline & & 60 & 90 & 120 & 60 & 90 & 120 & \\
\hline & & \multicolumn{6}{|c|}{ (Days) } & \\
\hline $\mathrm{T} 1$ & 20:80:0:0 & $2.95 \mathbf{a b}$ & $11.23 \mathbf{a}$ & $18.78 \mathbf{a}$ & $1.04 \mathbf{a}$ & $3.79 \mathbf{a}$ & $5.75 \mathbf{a}$ & $3.28 \mathbf{b}$ \\
\hline $\mathrm{T} 2$ & 0:80:20:0 & $2.17 \mathrm{c}$ & $2.70 \mathrm{c}$ & $3.89 \mathrm{c}$ & $0.80 \mathbf{b c}$ & $0.89 \mathrm{c}$ & $1.17 \mathrm{c}$ & $3.45 \mathrm{~b}$ \\
\hline $\mathrm{T} 3$ & $20: 60: 0: 20$ & $3.40 \mathrm{a}$ & $10.84 \mathbf{a}$ & $19.65 \mathbf{a}$ & $1.05 \mathrm{a}$ & $3.33 \mathbf{a}$ & $5.83 \mathbf{a}$ & $3.40 \mathrm{~b}$ \\
\hline $\mathrm{T} 4$ & 0:60:20:20 & $2.82 \mathbf{b}$ & $3.16 \mathrm{c}$ & $3.95 \mathrm{c}$ & $0.76 \mathrm{c}$ & $0.80 \mathbf{c}$ & $0.95 \mathrm{c}$ & $4.18 \mathrm{c}$ \\
\hline T5 & $10: 70: 10: 10$ & $2.90 \mathbf{a b}$ & $7.49 \mathbf{b}$ & $14.62 \mathbf{b}$ & $0.84 \mathbf{b}$ & $2.52 \mathbf{b}$ & $5.07 \mathrm{~b}$ & $2.89 \mathbf{a}$ \\
\hline
\end{tabular}

Legend: H - height; SD - stem diameter; H/SD - height/stem diameter ratio; BM - bovine manure; SAH - soil from A horizon; CP - compost of urban pruning waste; $\mathrm{V}$ - vermiculite. *Values followed by different letters in the column, for each date, differ from each other ( $\mathrm{p}<0.05$ ), by Kruskal-Wallis test.

FLORESTA, Curitiba, PR, v. 51, n. 2, p. 381-390, abril/jun 2021 
There was a significant difference between the substrates tested for the evaluated periods regarding SDM, RDM, TDM, SDM/RDM ratio and DQI of $C$. glandulosa seedlings (Table 6). The highest values of these variables were found in treatments T1, T3 and T5 at 90 days and in T1 and T3 at 120 days, except for the SDM/RDM ratio.

Tabela 6: Massa seca da parta aérea (SDM), massa seca das raízes (RDM), massa seca total (TDM), relação massa seca parte aérea/massa seca raiz (SDM/RDM) e índice de qualidade de Dickson (DQI) das mudas de $C$. glandulosa aos 90 e 120 dias após repicagem.

Table 6: Shoot dry mass (SDM), root dry mass (RDM), total dry mass (TDM), shoot dry mass/root dry mass ratio (SDM/RDM) and Dickson quality index (DQI) of C. glandulosa seedlings at 90 and 120 days after transplanting.

\begin{tabular}{|c|c|c|c|c|c|c|}
\hline \multirow{2}{*}{ Treat. } & \multirow{2}{*}{$\begin{array}{c}\text { Composition (\%) } \\
\text { BM:SAH:CP:V }\end{array}$} & SDM & RDM & TDM & SDM/RDM & \multirow{2}{*}{ DQI } \\
\hline & & \multicolumn{4}{|c|}{ (g) } & \\
\hline \multicolumn{7}{|c|}{90 DAYS } \\
\hline $\mathrm{T} 1$ & 20:80:0:0 & $2.49 \mathbf{a}$ & $0.90 \mathbf{a}$ & $3.40 \mathbf{a}$ & $2.77 \mathbf{a b}$ & - \\
\hline $\mathrm{T} 2$ & 0:80:20:0 & $0.04 \mathbf{b}$ & $0.01 \mathrm{c}$ & $0.05 \mathbf{b}$ & $4.89 \mathbf{a b}$ & - \\
\hline $\mathrm{T} 3$ & 20:60:0:20 & $2.07 \mathbf{a}$ & $0.80 \mathbf{a}$ & $2.88 \mathbf{a}$ & $2.54 \mathbf{a b}$ & - \\
\hline $\mathrm{T} 4$ & 0:60:20:20 & $0.02 \mathbf{b}$ & $0.01 \mathbf{b c}$ & $0.03 \mathbf{b}$ & $1.24 \mathbf{a}$ & - \\
\hline T5 & 10:70:10:10 & $1.09 \mathbf{a}$ & $0.36 \mathbf{a b}$ & $1.45 \mathbf{a}$ & $3.04 \mathbf{b}$ & - \\
\hline \multicolumn{7}{|c|}{120 DAYS } \\
\hline $\mathrm{T} 1$ & 20:80:0:0 & $5.83 \mathbf{a b}$ & $1.47 \mathbf{a b}$ & $7.30 \mathbf{a b}$ & $5.10 \mathrm{c}$ & $0.90 \mathrm{~b}$ \\
\hline $\mathrm{T} 2$ & 0:80:20:0 & $0.08 \mathbf{c}$ & $0.03 \mathbf{c}$ & $0.11 \mathbf{c}$ & $2.38 \mathbf{b}$ & $0.02 \mathbf{a}$ \\
\hline $\mathrm{T} 3$ & 20:60:0:20 & $6.20 \mathbf{a}$ & $2.15 \mathbf{a}$ & $8.35 \mathbf{a}$ & $2.90 \mathbf{b c}$ & $1.30 \mathrm{c}$ \\
\hline $\mathrm{T} 4$ & 0:60:20:20 & $0.04 \mathbf{c}$ & $0.03 \mathbf{c}$ & $0.06 \mathbf{c}$ & $1.40 \mathbf{a}$ & $0.01 \mathbf{a}$ \\
\hline T5 & 10:70:10:10 & $3.31 \mathbf{b}$ & $0.65 \mathbf{b}$ & $3.96 \mathbf{b}$ & $6.94 \mathrm{c}$ & $0.50 \mathbf{a b}$ \\
\hline
\end{tabular}

Legend: BM - bovine manure; SAH - soil from A horizon; $\mathrm{CP}$ - compost of urban pruning waste; V - vermiculite. *Values followed by different letters in the column differ from each other $(\mathrm{p}<0.05)$ by Kruskal-Wallis test.

Regarding the nutrients quantified in the shoots ( $\mathrm{SH}$ ) of the seedlings at 90 days (Table 7), the highest significant contents of $\mathrm{N}$ and $\mathrm{Mg}^{+2}$ were observed in treatments $\mathrm{T} 1, \mathrm{~T} 3$ and $\mathrm{T} 5$. For $\mathrm{P}$ and $\mathrm{Ca}^{+2}$ contents, the highest means were found in T3 and T5. Treatments T2 and T4 had the highest $\mathrm{K}^{+}$contents. At 120 days, treatments $\mathrm{T} 2$ and T4 maintained the highest means for $\mathrm{K}^{+}$, whereas T1, T3 and T5 had the highest contents of $\mathrm{N}, \mathrm{P}, \mathrm{Ca}^{+2}$ and $\mathrm{Mg}^{+2}$ (Table 7).

Tabela 7: Teores de macronutrientes da parte aérea (SH) e raiz (R) das mudas de C. glandulosa aos 90 e 120 dias. Table 7: Macronutrient contents in shoots (SH) and roots (R) of C. glandulosa seedlings at 90 and 120 days.

\begin{tabular}{|c|c|c|c|c|c|c|c|c|c|c|}
\hline \multirow{3}{*}{ Treat. } & \multicolumn{5}{|c|}{ SH } & \multicolumn{5}{|c|}{$\mathbf{R}$} \\
\hline & $\mathbf{N}$ & $\mathbf{P}$ & $\mathbf{K}^{+}$ & $\mathrm{Ca}^{+2}$ & $\mathrm{Mg}^{+2}$ & $\mathbf{N}$ & $\mathbf{P}$ & $\mathbf{K}^{+}$ & $\mathrm{Ca}^{+2}$ & $\mathbf{M g}^{+2}$ \\
\hline & \multicolumn{10}{|c|}{$\left(\mathrm{g} \mathrm{kg}^{-1}\right)$} \\
\hline \multicolumn{11}{|c|}{90 DAYS } \\
\hline $\mathrm{T} 1$ & $73.23 \mathbf{a}$ & $11.35 \mathrm{~b}$ & $0.11 \mathrm{~b}$ & $4.83 \mathrm{~b}$ & $3.51 \mathbf{a}$ & $58.80 \mathbf{a}$ & $17.61 \mathbf{a}$ & $0.16 \mathbf{b c}$ & $13.62 \mathbf{a}$ & $8.06 \mathbf{a b}$ \\
\hline $\mathrm{T} 2$ & 49.9 bc & $5.10 \mathrm{c}$ & $0.24 \mathbf{a}$ & $0.69 \mathrm{c}$ & $0.78 \mathbf{b}$ & $76.17 \mathbf{a}$ & $13.41 \mathbf{a}$ & $0.26 \mathbf{a}$ & $0.70 \mathbf{c}$ & $0.65 \mathrm{c}$ \\
\hline $\mathrm{T} 3$ & $80.97 \mathbf{a}$ & $14.94 \mathbf{a}$ & $0.09 \mathrm{c}$ & $7.28 \mathbf{a b}$ & $5.52 \mathbf{a}$ & $57.07 \mathbf{a}$ & $22.42 \mathbf{a}$ & $0.16 \mathbf{b c}$ & $19.76 \mathbf{a}$ & $12.35 \mathbf{a}$ \\
\hline $\mathrm{T} 4$ & $35.78 \mathrm{c}$ & $3.80 \mathrm{c}$ & $0.20 \mathbf{a b}$ & $0.90 \mathbf{c}$ & $0.90 \mathbf{b}$ & $84.43 \mathbf{a}$ & $18.51 \mathbf{a}$ & $0.23 \mathbf{a b}$ & $0.75 \mathrm{c}$ & $0.69 \mathrm{c}$ \\
\hline T5 & $64.10 \mathbf{a b}$ & $13.17 \mathbf{a b}$ & $0.09 \mathbf{c}$ & $8.95 \mathbf{a}$ & $4.24 \mathbf{a}$ & $55.32 \mathbf{a}$ & $15.11 \mathbf{a}$ & $0.14 \mathbf{c}$ & $16 \mathbf{a b}$ & $6.53 \mathbf{b}$ \\
\hline \multicolumn{11}{|c|}{120 DAYS } \\
\hline $\mathrm{T} 1$ & $63.25 \mathbf{a}$ & $8.70 \mathbf{a}$ & $0.13 \mathbf{b}$ & $7.34 \mathbf{a}$ & $3.78 \mathbf{a}$ & $50.66 \mathbf{a}$ & $16.86 \mathbf{b}$ & $0.08 \mathbf{b}$ & $14.78 \mathbf{b}$ & $6.32 \mathbf{b}$ \\
\hline $\mathrm{T} 2$ & 39 c & $4.18 \mathbf{b}$ & $0.14 \mathbf{a}$ & $2.40 \mathrm{~b}$ & $1.45 \mathrm{bc}$ & $66.74 \mathbf{a}$ & $8.78 \mathrm{~cd}$ & $0.19 \mathbf{a}$ & $1.11 \mathrm{c}$ & $0.72 \mathbf{c}$ \\
\hline $\mathrm{T} 3$ & $58.20 \mathbf{a b}$ & $9.10 \mathbf{a}$ & $0.08 \mathbf{b}$ & $9.46 \mathbf{a}$ & $5.34 \mathbf{a}$ & $56.99 \mathbf{a}$ & $25.70 \mathbf{a}$ & $0.08 \mathbf{b}$ & $29.37 \mathbf{a}$ & $11.33 \mathbf{a}$ \\
\hline $\mathrm{T} 4$ & $45.01 \mathrm{bc}$ & $5.01 \mathrm{~b}$ & $0.15 \mathbf{a}$ & $1.52 \mathrm{~b}$ & $1.22 \mathrm{c}$ & $57.82 \mathbf{a}$ & $8.04 \mathbf{d}$ & $0.15 \mathbf{a}$ & $1 \mathrm{c}$ & $0.94 \mathbf{c}$ \\
\hline $\mathrm{T} 5$ & $51.07 \mathbf{a b}$ & $8.07 \mathbf{a}$ & $0.08 \mathbf{b}$ & $6.18 \mathbf{a}$ & $3.40 \mathbf{a b}$ & $50.50 \mathbf{a}$ & 14.47 bc & $0.07 \mathbf{b}$ & $13.41 \mathbf{b}$ & $5.90 \mathrm{~b}$ \\
\hline
\end{tabular}

Legend: Treat. - treatment. SAH: soil from A horizon; CP: compost of urban pruning waste; $\mathrm{N}$ - nitrogen $\mathrm{P}$ - phosphorus; K - potassium; Ca - calcium; $\mathrm{Mg}$ - magnesium; $\mathrm{SH}$ - shoots; $\mathrm{R}$ - roots. *Values followed by different letters in the column differ from each other ( $\mathrm{p}<0.05$ ) by Tukey test. 
Treatments T2 and T4 showed the same pattern observed in the shoots for the roots of the seedlings, with statistically higher $\mathrm{K}^{+}$contents at 90 and 120 days (Table 7). Treatments $\mathrm{T} 1$, T3 and T5 were significantly superior at 90 days for $\mathrm{Ca}^{+2}$ contents, as well as $\mathrm{T} 1$ and $\mathrm{T} 3$ for $\mathrm{Mg}^{+2}$. At 120 days, the highest means of $\mathrm{P}, \mathrm{Ca}^{+2} \mathrm{and} \mathrm{Mg}^{+2}$ were found in the T3 treatment. There was no significant difference for $\mathrm{N}$ contents on both dates and for P at 90 days (Table 7).

\section{DISCUSSION}

It is observed that, among the different substrate compositions tested, those containing bovine manure are the most recommended for the production of $C$. glandulosa seedlings. The best development of seedlings in treatments with higher proportions of this waste possibly occurred due to its better chemical characteristics, as pointed out in the literature.

The variation in the components of the treatments and their proportions affected the chemical composition of the substrates. When bovine manure was added to the substrate composition, the values of $\mathrm{C} / \mathrm{N}$ ratio were lower, but still above the ideal range. According to Gonçalves and Poggiani (1996), materials with high C/N ratios (>18/1) generally have high activity of microorganisms, which consequently compete with the seedlings for nutrients. The $\mathrm{N}$ contents are below the recommendation of BRASIL (2009), which is $5 \mathrm{~g} \mathrm{~kg}^{-1}$. This pattern causes difficulties for the development of seedlings, because $\mathrm{N}$ is the most required nutrient among all others and its deficiency limits plant growth (BERTI et al., 2017).

The greater growth in height for treatments T3 and T1 (Table 5) occurred possibly due to the use of bovine manure in the composition of substrates, a component that led to an increase in fertility compared to treatments that do not have BM. On the other hand, the treatments with the highest percentage of $\mathrm{CP}$ and without BM in the substrate (T2 and T4) had the lowest means (Table 5). Gonçalves et al. (2000) recommend limits of height between 20 and $35 \mathrm{~cm}$ to verify the quality of seedlings produced in tubes. Despite using larger containers (Citropote ${ }^{\circledR}$ ) than tubes, the treatments with better development did not reach the recommended limits for height. However, for $\mathrm{T} 3$ and $\mathrm{T} 1$, the means reached were very close to the recommended one (19.65 and $18.78 \mathrm{~cm}$, respectively).

Shoot height and stem diameter of forest seedlings are two essential parameters for assessing seedling quality and for estimating survival after planting, parameters that are non-destructive, easy to measure and widely used in several studies (LISBOA et al., 2018; BERTI et al., 2017; FARIA et al., 2014). Regarding stem diameter, the observed behavior was the same as that for height, with treatments T3 and T1 being superior, and the lowest means verified for T2 and T4 (Table 5). Wendling and Dutra (2017), in studies with Eucalyptus camaldulensis, indicate a minimum of $2 \mathrm{~mm}$ for field planting. The T5 treatment, although not statistically equal to T3 and T1, had an average value higher than the minimum established, which is acceptable for a good development.

Considering the limits established by Araújo et al. (2017) for H/SD ratio from 5.4 to 8.1, no treatment had satisfactory results, but the ratio found in T4 was close to that indicated (Table 5). However, this treatment did not promote a satisfactory development, since the H/SD ratio was close to the reference ratio because of the low values of height and stem diameter. The small increments observed for shoot height and stem diameter in T4 remained in balance. Regardless of the value obtained, this variable cannot be evaluated alone (ABREU et al., 2017), which may cause an overestimation of development, as observed in this study.

Evaluating the growth of Schizolobium amazonicum Huber ex Ducke (paricá) seedlings produced in substrates based on three sources of organic waste (tree pruning, carnauba straw and charcoal powder) and soil from B horizon, Araújo et al. (2017) concluded that the formulation with the highest proportion of tree pruning compost ( $80 \%$ ) promoted the best seedling development at 52 days, finding values of 34.1 for $\mathrm{H}, 4.41$ for CD, and 7.54 for H/SD. This pattern differs from the values found in the present study, possibly due to the higher availability of $\mathrm{N}$, balancing the $\mathrm{C} / \mathrm{N}$ ratio in the organic compost used.

After evaluation of the growth and quality of Handroanthus heptaphyllus seedlings in substrate with bovine manure, sand and clay, at 120 days, Lisboa et al. (2018) found that the treatments containing 21 and $28 \%$ of BM promoted the best development of height, stem diameter and H/SD ratio, corroborating the results observed in this study. Melo et al. (2014) observed that BM had a negative influence on growth in height and stem diameter for the species Eremanthus erythropappus (candeia) and a positive influence for Eucalyptus grandis (Eucalyptus).

The results of dry biomass are directly related to the development of the seedlings, because treatments $\mathrm{T} 1$ and T3 led to significantly higher means when compared to the others, followed by T5 (Table 6). The greater growth of the roots in these treatments promoted a greater exploration of the substrate inside the containers and, consequently, greater absorption of water and nutrients, resulting in a better development of the seedlings.

The treatments with the highest proportion of $\mathrm{CP}$ were those that had the lowest values for all morphological variables, except T2 for SDM/RDM ratio at 90 days. However, the T5 treatment, with $10 \% \mathrm{CP}$, had higher values, together with T1 and T3 for the variables SDM, RDM and TDM at 90 days; and for DQI, at 
120 days, along with T2 and T4. From these results, it was possible to observe a tolerance of C. glandulosa seedlings to $10 \%$ of CP combined with $\mathrm{SAH}, \mathrm{BM}$ and V.

Faria et al. (2014) attributed the high values of biomass observed in the shoots and roots of Senna alata seedlings to the high levels of $\mathrm{Ca}^{+2}$ and $\mathrm{Mg}^{+2}$ present in the substrate, because $\mathrm{Ca}^{+2}$ is the element that promotes the greatest growth of the root system and $\mathrm{Mg}^{+2}$ has an important specific role in the activation of enzymes involved in respiration, photosynthesis and synthesis of DNA and RNA. Differing from the observation made by Faria $e t$ al. (2014), the T2 treatment, despite having adequate levels of $\mathrm{Ca}^{+2}$ and $\mathrm{Mg}^{+2}$ to promote a good biomass development, led to limited growth.

The stagnation in the development of seedlings in T2 and T4 probably occurred because of the low levels of $\mathrm{N}$ and $\mathrm{P}$ available, since $\mathrm{N}$ is required in large quantity for the production of new tissues and $\mathrm{N}$ and $\mathrm{P}$ are considered the nutrients that most limit plant growth and development (ABREU et al., 2017, BERTI et al., 2017; JOSÉ et al., 2009). For treatments that contain CP in their composition, it is inferred that they were subjected to the stress of competition for the available nutrients with the microorganisms responsible for the transformation and stabilization of organic waste (ABREU et al. 2017).

Through the analysis of the SDM/RDM ratio, it is possible to obtain a better understanding of these variables (ROCHA et al., 2013). According to Lisboa et al. (2018), the higher the SDM, the higher the photosynthetic rate of the plant; however, if the roots do not develop enough, problems with water stress and nutrient absorption capacity may occur, especially under field conditions. José et al. (2009) consider that this ratio must be lower than 2.0 for the root system to have a sufficiently size to allow the supply of water to the shoots, in seedlings produced in tubes $(50 \mathrm{~mL}$ and $150 \mathrm{~mL})$.

Taking into account the reference value described by José et al. (2009), for SDM/RDM ratio, treatments with unsatisfactory performance (T2 and T4) would be adequate and treatments with better development (T1, T3 and T5) would be above the desired, that is, with some of the compartments ( $\mathrm{SH}$ and/or R) disproportionate compared to the other. However, when considering the volume of the container used $(1.7 \mathrm{~L})$, C. glandulosa seedlings were expected to reach values above that found in the literature, as observed in T1, T3 and T5. The low values determined in T2 and T4 are due to the low fertility of their respective substrates. Caldeira et al. (2013) justify that the SDM/RDM ratio is lower in environments of lower fertility and can be considered a strategy of the plant to remove as much nutrients as possible under that condition.

The Dickson quality index (DQI) considers in its calculation the sturdiness (H/SD ratio) and the balance of biomass distribution in the seedling (TDM and SDM/RDM ratio). The higher the DQI value, the better the quality of the seedlings within that lot, as high values are achieved when the seedlings have low values of H/SD ratio (seedlings without etiolation), low values of SDM/RDM ratio (seedlings with root system capable of supplying the aerial part), and high value of TDM (ABREU et al., 2017; CALDEIRA et al., 2013). As observed for the quality parameters previously evaluated, T3 had the highest mean (1.30) for DQI, followed by T1 (0.90) and T5 (0.50). The values verified in T2 and T4 for this variable are considered insufficient. It is worth pointing out that, for any of the components used in substrate formulations, attention should be paid to the origin (MELO et al., 2014), and in the case of this study, regarding the maturation and stabilization of the compost of tree pruning waste when subjected to the bioprocess of composting, as it can affect the quality of the material and the development of seedlings.

For treatments T2 and T4, the highest contents of potassium $\left(\mathrm{K}^{+}\right)$, in both shoots and roots, in the two evaluation periods (Table 7), possibly occurred due to the strategy of seedlings to resist stress conditions, such as low fertility and high temperatures, because $\mathrm{K}^{+}$has no structural function in the plant, but is associated with its greater resistance when subjected to adverse conditions, due to its function in stomatal opening and closing (BERTI et al., 2017).

In general, it can be inferred that the compost of urban pruning waste contributed negatively to the growth of $C$. glandulosa seedlings. It was verified that seedlings that received $\mathrm{CP}$ in greater quantity in the substrate composition showed lower quality compared to the treatment with only bovine manure, soil from A horizon and vermiculite. The results presented in this study do not corroborate the expected performance for an organic compost of plant waste, demonstrating the need for greater caution in the processes of bio-stabilization of waste for subsequent use.

The composition with $10 \% \mathrm{BM}+70 \% \mathrm{SAH}+10 \% \mathrm{CP}+10 \% \mathrm{~V}$ (T5) promoted medium development for the seedlings, pointing to a tolerance of the species $C$. glandulosa to this compost. It is also worth mentioning that there is a great genetic diversity of native forest species, so further studies are needed in order to cover a greater number of species. Each species may require different nutritional composition because it has a distinct autoecology (ABREU et al., 2017), and the quality of the pruning waste compost used is variable.

FLORESTA, Curitiba, PR, v. 51, n. 2, p. 381-390, abril/jun 2021.

Mendonça, V. M. M. et.al.

ISSN eletrônico 1982-4688 


\section{CONCLUSIONS}

- The compost of urban pruning waste can be used in the composition of substrates, but it needs to be combined with other components to balance nutrition and physical characteristics of the substrate and there must be better stabilization in the composting process.

- In the composition of the substrates for C. glandulosa seedlings, the addition of CP promoted medium - regular development in a smaller proportion, with the formulation $10 \%$ bovine manure $+70 \%$ soil from A horizon + $10 \%$ compost of urban pruning waste $+10 \%$ vermiculite.

- The seedlings produced in this study with compost of tree pruning waste did not reach minimum standards for use.

\section{ACKNOWLEDGMENTS}

This study was carried out with support from the Coordination for the Improvement of Higher Education Personnel - Brazil (CAPES) - Financing Code 001, and funded by the Association for Pro-Management of the Waters of the Paraíba do Sul River Basin (AGEVAP).

\section{REFERENCES}

ASSOCIAÇÃO BRASILEIRA DE NORMAS TÉCNICAS - ABNT. (NBR 10.007). Amostragem de resíduos sólidos, 2004.

ABREU, A. H. M.; LELES, P. S. S.; MELO; MELO, L. A.; OLIVEIRA, R. R.; FERREIRA, D. H. A. A. Caracterização e potencial de susbtratos formulados com biossólido na produção de mudas de Schinus terebinthifolius Raddi. E Handroanthus heptaphyllus (vell.) Mattos. Ciência Florestal, Santa Maria, v. 27, n. 4, p. $1179-1190,2017$.

ARAÚJO, E. F.; AGUIAR, A. S.; ARAUCO, A. M. S. Crescimento e qualidade de mudas de paricá produzidas em substratos à base de resíduos orgânicos. Revista Nativa, Sinop - MT, v. 5, n. 1, p. 16-23, 2017

BERTI, C. L. F.; KAMADA, T.; SILVA, M. P.; MENEZES, J. F. S.; OLIVEIRA, A. C. S. Crescimento de mudas de baru em substrato enriquecido com o nitrogênio, fósforo e potássio. Cultura Agronômica, Ilha Solteira, v. 26, n. 2, p. $191-202,2017$.

BRANCALION, P. H. S.; MONDO, V. H. V.; COELHO, A. D. L. Escarificação química para a superação da dormência de sementes de saguaraji-vermelho (Colubrina glandulosa Perk. - Rhamnaceae). Revista Árvore, Viçosa, v. 35, n. 1, p. 119 - 124, 2011.

CALDEIRA, M. V. W.; DELARMELINA, W. M.; FARIA, J. C. T.; JUANHOL, R. S. Substratos alternativos na produção de mudas de Chamaecrista desvauxi. Revista Árvore, Viçosa, v. 37, n. 1, p. 31 - 39, 2013

CAMARA, R.; FONSECA JÚNIOR, A. M.; SOUSA, A. C. O.; PEREIRA, M. G.; OLIVEIRA JÚNIOR, J. Q. Influência do substrato e inoculação micorrízica na produção de mudas de Colubrina glandulosa Perkins. Floresta, Curitiba, v. 47, n. 4, p. $449-458,2017$.

DE BOODT, M.; VERDONCK, O. The physical properties of the substrates in horticulture. Acta Horticulturae, Wageningen, n. 26, p.37 - 44, 1972.

DICKSON, A.; LEAF, A.; HOSNER, J. F. Quality appraisal of white spruce and white pine seedling stock in nurseries. Forestry chronicle, Ottawa, v.36, p. 10-13, 1960.

FARIA, J. C. T.; CALDEIRA, V. W.; DELARMINA, W. M.; ROCHA, R. L. F. Uso de resíduos orgânicos na produção de mudas de Senna alata (L.) Roxb. Ecologia e Nutrição Florestal, Santa Maria, v. 1, n. 3, p. 133 146, 2014.

GAZOLA, T. GUALBERTO, R. DIAS, M. F.; CIPOLA FILHO, M. L.; BELAPART, D.; CASTRO, E. B. Avaliação de substratos alternativos na produção de mudas e desenvolvimento de plantas de alface. UNIMAR Ciências, Marília, v. 24, n. 1-2, p. 33 - 39, 2015.

GONÇALVES, J. L. M.; SANTARELli, E. G.; MORAES NETTO, S. P.; MANARA, M. P.; STAPE, J. L. Produção de mudas de espécies nativas: substrato, nutrição, sombreamento e fertilização. In: GONÇALVES, J. L. M.; BENEDETTI, V. Nutrição e fertilização florestal, Piracicaba: Ed. ESALQ/USP, 2000, 427 p. 
GONÇALVES, J. L. M.; POGGIANI, F. Substrato para produção de mudas florestais. In: SOLO-SUELOCONGRESSO LATINO AMERICANO DE CIÊNCIA DO SOLO, 13, 1996. Águas de Lindóia-SP. Relação de trabalhos. Águas de Lindóia: SLCS/SBCS/ESALQ/USP/CEA-ESALQ/USP/SBM, 1996. 1 CD ROM.

JOSÉ, A. C.; DAVIDE, A. C.; OLIVEIRA, S. L. Efeito do volume do tubete, tipo e dosagem de adubo na produção de mudas de aroeira (Schinus terebinthifolia Raddi). Agrarian, Dourados, v. 2, n. 3, p. 73-86, 2009.

LisboA, A. C.; MElo JÚNIOR, C. J. A. H. TAVARES, F. P. A. T.; AlMEIDA, R. B.; MELO, L. A.; MAGISTRALI, I. C. Crescimento e qualidade de mudas de Handroanthus heptaphyllus em substrato com esterco bovino. Pesquisa Florestal Brasileira, Colombo, v. 38, p. 1 - 6, 2018.

WENDLING, I.; DUTRA, L. F. Produção de mudas de eucalipto por sementes. In: WENDLING I \& DUTRA LF (2. Ed.) Produção de mudas de eucalipto. Brasília, Ed. Embrapa Florestas, 2017, 192 p.

LORENZI, H. (2002) Árvores brasileiras: manual de identificação e cultivo de plantas arbóreas do Brasil. 4 ed. Nova Odessa, Editora Plantarum, 2002.

BRASIL. MINISTÉRIO DA AGRICULTURA, PECUÁRIA E ABASTECIMENTO (MAPA). Secretaria de Defesa Agropecuária (SDA). Instrução Normativa SDA No 17 de 21 de maio de 2007. Dispõe sobre métodos analíticos oficiais para análise de substratos e condicionadores de solos. Diário Oficial da União, Brasília, DF, vinte e um de maio de 2007.

BRASIL. MINISTÉRIO DA AGRICULTURA, PECUÁRIA E ABASTECIMENTO (MAPA). Secretaria de Defesa Agropecuária (SDA). Instrução Normativa SDA Nº 25 de 23 de julho de 2009. Dispõe sobre normas sobre as especificações e as garantias, as tolerâncias, o registro, a embalagem e a rotulagem dos fertilizantes orgânicos simples, mistos, compostos, organominerais e biofertilizantes destinados à agricultura. Diário Oficial da União, Brasília, DF, vinte e três de julho de 2009.

MElO, L. A.; PEREIRA, G. A.; MOREIRA, E. J. C.; DAVIDE, A. C.; SILVA, E. V.; TEIXEIRA, L. A. F. Crescimento de mudas de Eucalyptus grandis e Eremanthus erythropappus sob diferentes formulações de substrato. Floresta e Ambiente, Seropédica, v. 21, n. 2, p. 234 - 242, 2014.

MESQUITA, E. F.; CHAVEZ, L. H. G.; FREITAS, B. V.; SILVA, G. A.; SOUSA, M. V. Produção de mudas de mamoeiro em função de substratos contendo esterco bovino e volumes de recipientes. Revista Brasileira de Ciências Agrárias, Pernambuco, v. 7, n. 1, p. 58 - 65, 2012.

ROCHA, J. H. T. BACKES, C.; DIOGO, F. A.; PASCOTTO, K. B. Composto de lodo de esgoto como substrato para mudas de eucalipto. Pesquisa Florestal Brasileira, Colombo, v. 33, n. 73, p. 27 - 36, 2013.

SILVA, R. F.; MARCO, R.; ALMEIDA, H. S. GROLLI, A. L. Proporções de vermicomposto e vermiculita na produção de muda de timbaúva e angico-vermelho. Holos, Natal, v. 8, p. 33 - 41, 2017.

TEDESCO, M. J.; GIANELlO, C.; BISSANI, C. A.; BOHNEN, H. \& VOLKWEISS, S.J. Análises de solo, plantas e outros materiais. Boletim técnico, n. 5. 2 Ed. Porto Alegre, UFRS, 174 p. 1995.

TEIXEIRA, P. C.; DONAGEMA, G. K.; FONTANA, A.; TEIXEIRA, W. G. (Eds.). Manual de métodos de análise de solo. Rio de Janeiro, $3^{\mathrm{a}}$ ed. rev. e ampl. - Brasília, DF: Embrapa, 2017. 573 p. 